\title{
Wintering area and migration routes for Ortolan Buntings Emberiza hortulana from Sweden determined with light-geologgers
}

\author{
Övervintringsområde och flyttvägar för svenska ortolansparvar bestämda med \\ hjälp av ljusloggar
}

GUNNAR SELSTAM, JAN SONDELL \& PETER OLSSON

\begin{abstract}
The decrease of Ortolan Bunting Emberiza hortulana in Western Europe over the last five decades has caused serious concern for the survival of this species in Sweden. In order to find out the migration routes and wintering location, we equipped several males with geologgers. Our data show annual cycles of migrations routes, wintering grounds and time schedules for seven re-trapped birds. The wintering area in West Africa is savannah woodland in a mountainous landscape in Mali and Guinea. The migration routes follow more or less the great circle between the breeding and wintering areas. Most birds were

likely to have passed the well-known Ortolan catching area in les Landes south of Bordeaux in France during autumn migration.

Gunnar Selstam, Köpmansgatan 40, SE-456 62 Hunnebostrand, gunnar.selstam@molbiol.umu.se

Jan Sondell, Rulleuddsvägen 10, SE-178 51 Ekerö, Sweden,jan.sondell@telia.com

Peter Olsson, Lindmätaregatan 2, SE-218 38 Bunkeflostrand, Sweden, peter.olsson.mail@gmail.com
\end{abstract}

Received 5 February 2015, Accepted 24 March 2015, Editor: R. Ekholm

\section{Introduction}

The Ortolan Bunting population in Western Europe has decreased dramatically during many decades (Claessens 1994, Tryjanowski 2000, Vepsäläinen 2005). In Eastern Europe the Ortolan Bunting has probably also decreased, although the extent is unknown since profound reviews are lacking. In southern Sweden the Ortolan Bunting has declined dramatically over several decades (Stolt 1996). Studies corroborating this decline have been going on at Kvismaren close to the town of Örebro in Sweden from the middle 1960s (Runesson 1996), managed by Kvismare Bird Observatory. Active measures to support the population at Kvismaren were started in 2009 (Sondell \& Runesson 2010) when thinning of groves was made to create better habitats and singing posts in the open farmland. In 2011 the Kvismare Bird Observatory project merged with a newly started similar project within SOF BirdLife Sweden. Based on these studies, the following three factors are considered as the most likely causes of the decline (Sondell et al. 2011): (1) changes in the agricultural breeding habitat influencing production of offspring, (2) hunting or catching along the migration route, especially in France, and (3) factors affecting the survival at the wintering grounds and during migration.

In a small region in SW France between the Bay of Biscay, the Pyrenees and the pine forests south of Bordeaux where many Ortolan Buntings are passing by, there is a limited agricultural area where catching of Ortolan Buntings is going on. The aim is human consumption after fattening up the birds. Before EU banned the actual hunt in 1999 some 50000 birds were caught annually (JS, own observations, and Mount 2010). Today there are no catching figures available but it is probable that the catch is still substantial (bulletins from Ligue pour la protection des oiseaux, $L P O$ ).

Furthermore the location and possible detrimental influences on the wintering grounds was unknown. Stolt $(1977,1997)$ showed ring recoveries from southern Sweden and Finland that indicated a SW migration route towards Spain. However, no recoveries were found south of Morocco. Walther et al. (2010) showed in a simulation aiming to point out areas for special protection in Africa that suitable wintering areas for Ortolans followed a rather narrow band along the 10th parallel across the continent. Thoma \& Menz (2014) recently presented a comprehensive review of all published and also unpublished records of the species in West Africa. 
Most observations originated from Mauritania but there were also reports further south. They concluded that "the core wintering area is most likely to be in highland areas of Guinea, around Mount Nimba in Guinea-Liberia and in the Tingi and Loma Mountains in Sierra Leone."

Our aim was to find the wintering grounds, and to track the routes and stopover areas by mounting light-geologgers on the Ortolan Buntings. A logger is a small electronic unit containing a light sensor, a computer chip including a clock, a thermometer, a memory and a battery, all together weighing approx. 0.7 gram. Such small units have been commercially available for some years. By knowing time of dawn and sunsets, generated by a light threshold value, it is possible to calculate longitude and latitude for the actual bird location. The accuracy is not very high, but fair enough to get an understanding of flyways and wintering areas (Stutchbury et al. 2009). Some two weeks around the equinoxes when night and day are of similar length all over Earth an accuracy problem is constituted in the latitude. The accuracy can, however, be somewhat limited by considering flight speed and direction as showed for studies on the Great Reed Warbler Acrocephalus arundinaceus at Kvismaren, where a logger study was recently carried out concerning the migration strategies (Lemke et al. 2013).

The Ortolan Bunting population still remaining at Kvismaren is small and thus very vulnerable. The stronghold of Ortolan Buntings in Sweden is the Umeå county in Västerbotten, northern Sweden (Ottosson et al. 2012, Sondell et al. 2013), and this area was used for equipping five out of

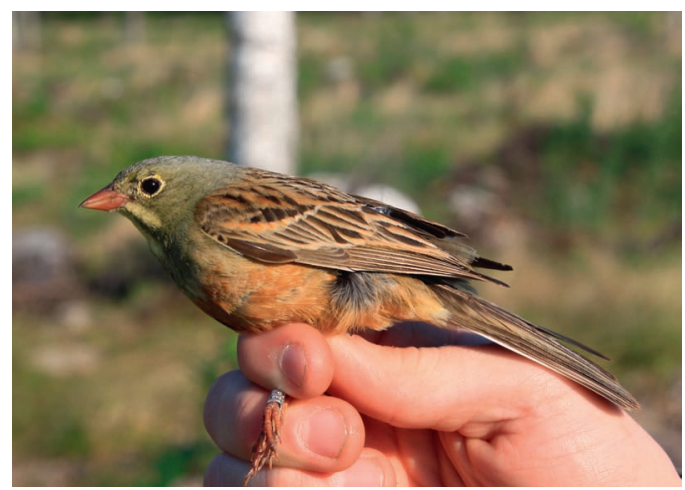

Figure 1. Ortolan Bunting with a logger on its back. The small 0.7 gram sensor is almost invisible. Photo: Gunnar Selstam.

Ortolansparv med logger på ryggen. Den lilla $0.7 \mathrm{~g}$ sensorn syns nästan inte. seven recovered geolocators to the birds. One bird was equipped further north, at Luleå in Norrbotten county, and one to the south at Kvismaren. The distance in between is $900 \mathrm{~km}$.

\section{Methods}

\section{Field work}

Ortolan territories from earlier years were searched and singing males were identified. Mist nets were placed next to the singing bird with a MP3-player close to the net. The handling procedure took approximately 15 minutes, and included ringing and a colour ring on left leg with an alphanumerical code. The geologger, manufactured by Migrate Technology Ltd, Cambridge, UK (type PC 65C27) was attached according to the manufacturer's description (Figure 1). Shortly, a $1.5 \mathrm{~mm}$ broad woven and slightly waxed nylon band was fitted through a hole in the front of the light logger and then around the legs of the bird and tied at the rear end of the logger. The square knot was secured with instantly drying glue. Care was taken that free ends were glued to the knot so that no ends were sticking out (except in one case, where the free end, 4 $\mathrm{mm}$ long, had scraped the innermost tertial). The distance between the light logger and the back skin was approximately $6 \mathrm{~mm}$ (except one case with 12 $\mathrm{mm})$. This latter was recovered and the logger had slid to the side and under the wing, but the stalk had registered light equally well. After attachment, feathers were carefully corrected under and around the logger. When the bird was released, it resumed singing or foraging within 30 minutes in all cases where the bird could be followed. No further attempts to check the presence was done in order not to disturb. The weight of the loggers including harness was approx. 0.7 gram.

Re-trapping next year was very difficult. Many of the birds equipped with loggers could not be caught despite time-consuming trials. The most probable reasons were that males had learned from last year's trapping and it was now easier for them to avoid the nets in the open terrain. It is also possible they could separate playback sound from the song of real competitors.

After re-trapping, the light logger data was downloaded via an interface that was purchased from the manufacturer. Data was downloaded successfully in six out of seven cases. Data from one bird was recovered by the manufacturer and only covered the period June 2013 to March 2014. After trapping, the birds were carefully inspected. Feath- 
ers around and under the light loggers were in all cases properly in order. No wearing by the lines or on the back or any other visible anatomical influence was seen and new feathers were seen under and around the light loggers and along the paths of the lines.

\section{Analysis of geolocator data}

Analysis of light logger data were based on established methods, i.e. implementing a light level threshold to identify twilight times, and using a calibrated SEA (Sun Elevation Angle) to estimate geographical positions (Hill \& Braun 2001, Ekström 2004).

The light data were decompressed using the software IntegeoIF ver. 1.0 (Migrate Technology). All subsequent data processing was performed in the program R (R Core Team 2013). Twilight events (sunrises and sunsets) were identified by using a light threshold of 2 lux. Twilight times were recognized as the first and last time during a day that the light value crossed the threshold value. Sunset events were then advanced by $4 \mathrm{~min}$, to correct for the time lag due to the device's logging interval (J. Fox, pers. com.). We included all sunrise and sunset transitions, i.e. we did not remove suspected outlier transitions except for a few obvious artificial light peaks at night during migration periods. These light peaks were interpreted as due to lightening.

Stationary periods were initially estimated using a change point analysis as function of the ChangeLight in the R package GeoLight (Lisovski \& Hahn 2013). However, in contrast to the GeoLight package that uses change point analysis for twilights, we computed the midday and midnight times, which we further compensated by the equation of time before estimating stationary periods. The resulting periods were then manually adjusted. To help analyse the stationary period's length we inspected the following estimates or measurement as a function of time: times of midday and midnight, daily/nightly latitudes. Since the loggers used, also record $\mathrm{min} / \mathrm{max}$ temperature, we also used temperature profiles to verify the start and end of stationary periods. Since latitude is dependent on the SEA used, latitudes were estimated and plotted using a range of SEA values from -10 to 2 degrees with a 0.2 degree step. During stationary periods we expected times of midday and midnight and latitudes to be stable and to be evenly and randomly distributed, with deviations outside the period. Min/max temperature over time was an additional criterion used to adjust stationary periods; we expected stable temperature profiles within a stationary period but temperatures profiles outside a period to deviate. Most periods did not require manual adjustments of their start and end. No period were adjusted with more than 48 hours at their start or end.

Median calibration SEAs were estimated on board the birds using periods of presumed position i.e. at the deployment site, (see previous paragraph how stationary periods were identified). We also used a Hill-Ekström calibration (Hill \& Braun 2001, Ekström 2004, Lisovski \& Hahn 2013) for the main wintering period, lasting from $>92$ to 171 days. On board bird calibration SEA and Hill-Ekström calibration SEA differed by $<0.01$ to $0.5^{\circ}$ for all loggers.

To estimate each period's position, we used estimated calibration-SEA as above. For long winter periods we used Hill-Ekström calibration-SEA. For each stationary period we used the calibratedSEA to compute median longitude and latitude. We computed median position estimates since daily/ nightly latitudes and longitudes within a period were in most cases not normally distributed. Positions were computed using the $\mathrm{R}$ package GeoLight. Because differences in day length are very small close to equinox, latitude estimates are highly uncertain in those periods and latitudes during approximately 14 days before and 14 days after an equinox were not calculated. Positions during the four week period spanning an equinox were calculated using standard astronomical algorithms by Meeus (1991) similar to the GeoLight package. Positions estimated with those algorithms during other periods were the same as estimated using GeoLight.

To estimate errors, we propagated the calibration-SEA errors using Monte Carlo error propagation. We used bootstrapping to estimate the error of the median calibration SEAs, using 10000 repetitions. We randomly sampled SEAs with replacement from the calibration periods sunrises and sunsets SEAs. The median SEA was computed for each repetition. For each bootstrapped median SEA the median longitude and latitude was computed. This gave distributions of median longitudes and latitudes from which confidence limits were estimated using quartiles.

Maps were drawn using the $\mathrm{R}$ package maps (Becker \& Wilks 2013). A p-value of less than 0.05 was considered significant. 


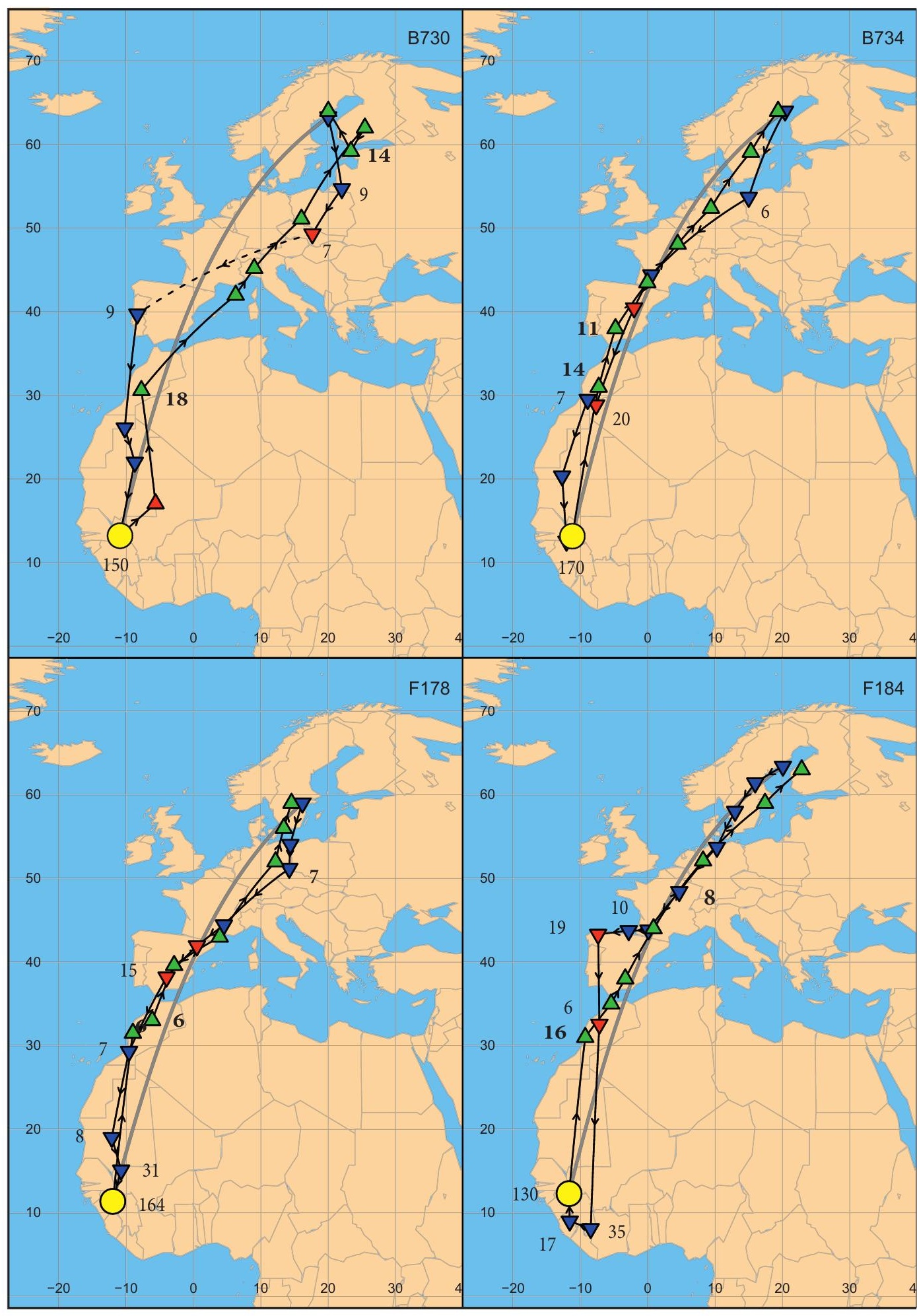




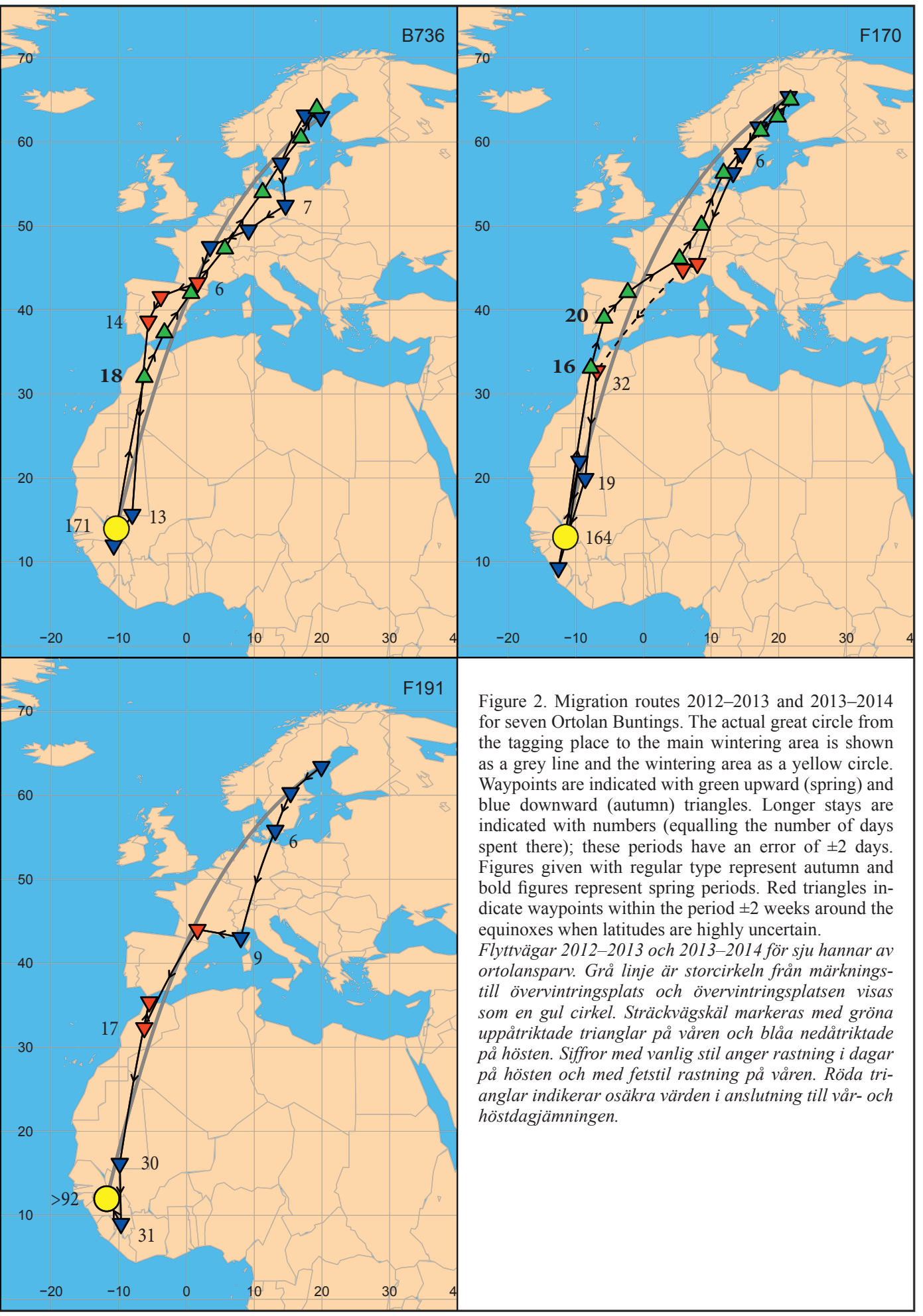




\section{Results}

To identify and analyse Swedish Ortolan Bunting migration and wintering habits, we equipped in all 45 Ortolan Buntings with light geolocators, 10 in 2012 and 29 in 2013 in northern Sweden and another 6 in southern Sweden in 2013. The small population in the latter region was considered too vulnerable for extensive catching. Three loggers were recovered in 2013 and 4 in 2014. In 2013, 17 territories were specially searched and 10 males with colour rings or loggers could be identified. The returning rate was thus approximately $60 \%$.

The birds started their autumn migration during August (10-31 August, median 24 August, mean 21.2; Appendix). Most birds had stopovers for about a week; north of the 50th parallel (Figure 2 $\&$ Appendix). One bird deviated from the others and initially took a southward route east of the Baltic Sea, Figure 2. All the birds made stopovers on the Iberian Peninsula or in Morocco, lasting from 6 to 32 days. The analysis indicates that several of the birds have passed the French county les Landes south of Bordeaux. Due to the uncertainties around equinox we were unable to determine if any of the birds passed the actual hunting area. However, we cannot exclude that all birds passed this area.

After arriving south of the Sahara, all birds have stayed at one or two locations up to 35 days before arriving at the main wintering grounds where all 6 birds with complete data stayed for approximately $5 \frac{1}{2}$ months (Appendix and Figure $2 \& 3$ ). The autumn migration lasted on average 56 days (42 to 64 days) from beginning of migration in Sweden until arriving at the first wintering/stopover location south of Sahara. The mean migration distance and speed were $6020 \mathrm{~km}$ and $114 \mathrm{~km} /$ day, respectively (Appendix).

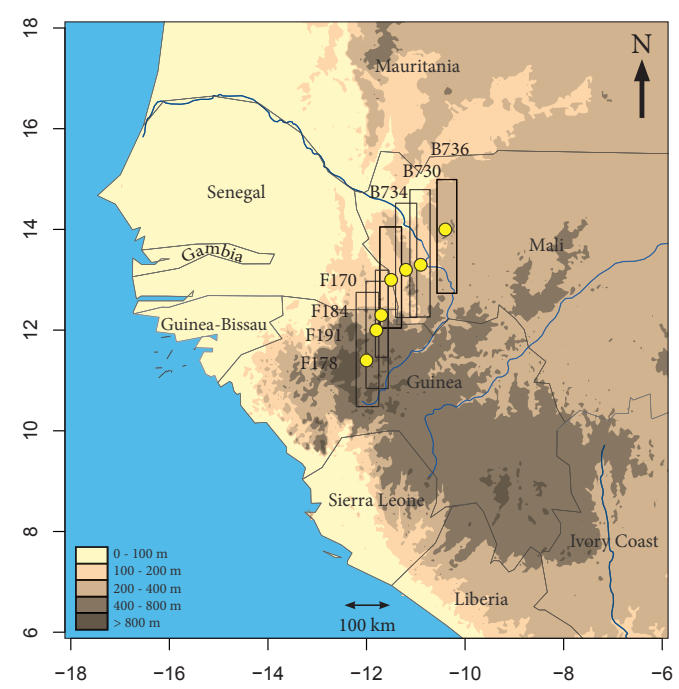

Figure 3. Wintering areas for seven males of Ortolan Bunting. The points are median coordinates during the number of days indicated in Figure 2. The surrounding squares illustrate a $95 \%$ confidence interval of the median longitude and latitude. Altitude of the terrain is given in 100 meter intervals. The Senegal (towards NW) and the Niger rivers (towards E) are originating in the actual mountainous area. Övervintringsområden för sju hannar av ortolansparv. Punkterna är mediankoordinater under det antal dagar som anges i Figur 2. Rektanglarna omkring indikerar osäkerheten i longitud- och latitudvärdena i form av ett 95\% konfindesintervall av mediankoordianterna. Terrängens höjd anges i 100-metersintervall. Senegalfloden (mot nordväst) och Nigerfloden (mot öster) rinner upp i detta bergmassiv.

After arriving in West Africa, one bird wintered on the same location until spring migration. The other birds have visited 1-2 locations for up to 61 days before arriving at the main wintering locations. At the main wintering locations in West

Table 1. Time table of migration activities.

Tidtabell för start och slut på sträckaktiviteter.

\begin{tabular}{llll}
\hline Migration activity & $\begin{array}{l}\text { Average } \\
\text { date } \\
\text { Medel- } \\
\text { Tytum av sträckaktivitet }\end{array}$ & $\begin{array}{l}\text { First and last } \\
\text { date } \\
\text { Tidigaste och } \\
\text { senaste datum }\end{array}$ & $\begin{array}{l}\text { Stamdard } \\
\text { deviation } \\
\text { Standard- } \\
\text { avvikelse }\end{array}$ \\
\hline $\begin{array}{l}\text { Departure from breeding area } \\
\text { Avflyttning från häckningsplatsen }\end{array}$ & August 22 & August 10-31 & \pm 4.3 days \\
$\begin{array}{l}\text { Arrival in wintering area } \\
\text { Ankomst till vinterkvarteret }\end{array}$ & October 12 & October 6-22 & \pm 5.1 days \\
$\begin{array}{l}\text { Departure from wintering area } \\
\text { Avflyttning frän vinterkvarteret } \\
\text { Arrival in breeding area } \\
\text { Ankomst till häckningsplatsen }\end{array}$ & April 5 & March 22 - April 15 & \pm 12.0 days \\
\hline
\end{tabular}


Africa (south-western Mali and northern Guinea) the birds stayed 150-182 days (mean period for 6 males were 167 days or $5 \frac{1}{2}$ months).

The birds started their spring migration in late March (22nd) or first half of April (4th to 15th, median 7 April, mean 5 April; Table 1). All birds arrived a few days later to stopovers in Morocco or Spain, lasting from 5 to 18 days. For one of the birds it is unclear if it passed Sahara before its first stopover or not. Several of the birds have been staying at two locations in Morocco or Spain for up to totally 25 days. Two birds stopped also in central Europe (6 days) and Finland (14 days; Figure 2). The spring migration took on average 40 days (33 to 48 ). The mean migration distance and speed were $6080 \mathrm{~km}$ and $158 \mathrm{~km} /$ day, respectively (Appendix).

The length of the migration period was shorter for spring migration compared to the autumn migration (paired t-test, $\mathrm{t}=3.4993, \mathrm{df}=5, \mathrm{p}=0.017$ ). The migration speed was also higher in the spring (paired t-test, $\mathrm{t}=-3.5568, \mathrm{df}=5, \mathrm{p}=0.016$ ).

In order to get an idea about the habitat used and behaviour at the winter area we compared light intensities recorded by the loggers. From these data we can see that the maximum light intensity (65 000 lux) was reached for all our seven light loggers parts of the days at breeding grounds in Sweden in May (e. g. week 21, late May). In Africa the maximum light values logged were much lower, the highest values for five out of seven loggers in week 4 (late January) were between 10000 and 30000 lux. The other two loggers momentarily reached maximum values.

\section{Discussion}

\section{Migration routes}

The flyway for the Ortolan Buntings both to and from the winter grounds more or less follows the great circle (Figure 2). The autumn migration takes place close to the equinoxes and most waypoints are thus uncertain. However most birds probably passes the French county les Landes south of Bordeaux where illegal trapping frequently is going on (Mount 2010, own observations, JS). We cannot exclude any of the birds passing that area. Our data do not indicate that the birds have a stopover for a few days in the area with known hunting. However migrating birds are probably very much attracted by the calls from caged birds at the catching stations.

There are some stopovers in northern Europe and some longer ones when the birds are about to reach their final destination in Africa. In spring the migration proceeds faster (mean value is 40 days compared to 56 days). All birds have longer stops in Morocco and two of them also in Spain. The bird B730 diverges mostly from the great circle and has clearly passed east of the Baltic Sea, both in autumn and in spring.

\section{Wintering grounds}

The seven males all had their wintering grounds in West Africa within a limited area of roughly some 40 000-50 000 square kilometres. All birds with complete data $(n=6)$ were staying on average for approximately $5 \frac{1}{2}$ months (Appendix).

The wintering area is situated at the northern slopes of the Fouta Djallon mountain range (Figure $3)$. According to own interpretations from aerial photos (Google Earth maps) the ground is covered with sparse savannah forest interrupted by brook ravines but also cultivated areas (Figure 4). Part of the ground is periodically burnt (Tom Averza, pers. com.). The precipitation is fairly high (MacDonald 1986) in the mountains, and they are also the source of three big rivers: Senegal, Gambia and Niger.

The two largest flocks of Ortolan Buntings ever reported from West Africa were observed at the airport of Labé, central Guinea $\left(11.19 .7^{\circ} \mathrm{N}\right.$; 12.18. $1^{\circ} \mathrm{W}$ ) (Thoma \& Menz 2014, Tom Averza, pers. com). The birds were seen on partly burnt grassland close to the air strip. The winter areas for all our tagged Ortolan males are situated between 50 and $350 \mathrm{~km}$ from Labé. The Fouta Djallon highlands are evidently a significant district for winter-

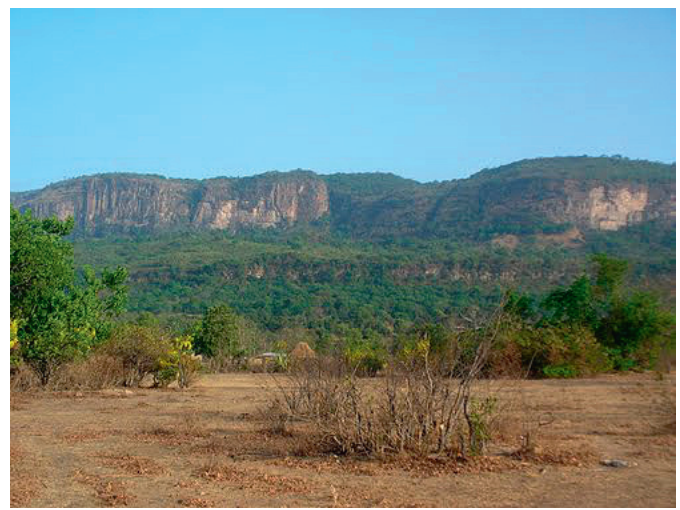

Figure 4. Habitat in Guinea close to the wintering site of Ortolan Bunting No. F178. Photo from Google Earth uploaded by Pstrosatko.

Biotop från Guinea nära övervintringsområdet för ortolansparven nummer F178. 
ing Ortolan Buntings. The wintering area predicted by Thoma \& Menz (2014) was thus fairly correct. However we have not got any indications of coordinates further south than in Guinea.

Important grains in the area are millet and sorghum (US Department of State 2004). At least millet probably attracts the ortolan as caught birds in France are fattened up with that grain (Steen 2014). Millet cobs are also used to entice the Ortolan Buntings to the traps in France (own observations, JS). The actual crops are tall (1.5-3 meter) creating a rather dark and relatively cold climate at the bare ground between the plants. We know from Sweden (Uppland) that Ortolan Buntings may be found singing in willow plantations for energy production where the soil between the willow rows also is almost bare.

In the breeding habitat singings males are periodically sitting on a song post in bright sunshine and during these periods the loggers reach their maximum light values possible to record (65000 lux). At the wintering habitat, where the sunshine close to the equator is at least as strong, we mostly observe daily peak figures of 10000 to 30000 lux. That indicates that the Ortolan Buntings during the winter months normally avoid showing up in open areas. Feeding may occur sheltered on the ground underneath the canopy, in the shrub vegetation or in the cornfields. That may explain why there are relatively few Ortolan Bunting observation reports during the wintering period.

\section{Time cycle}

The yearly time cycle is on average divided in more than five months at wintering and less than four months at breeding grounds. The remaining three months are migration months including stopovers of different lengths. Particularly the spring arrival in Sweden is strongly synchronized (Table 1). Also departure and arrival in autumn is fairly synchronized.

The Ortolan Bunting has a suspended moult (Svensson 1992, the moult cards or Kvismare Bird Observatory, and own (JS) inspection of skins at Museum of Natural History, Stockholm). This is very uncommon for smaller Fennoscandian passerines (Svensson 1992) and probably means that the species is in a hurry to migrate southwards (Table 1). The Ortolan most likely completes the moult of the wing feathers at the wintering grounds. Looking at the migration data there seems to be no hurry except for late breeding pairs. All birds leave their breeding grounds in the latter part of August but on their way southwards most birds make a 1-2 weeks stop in northern Europe. However this stop is not long enough for them to complete the moult. Possibly the moult pattern has developed when the Ortolan Bunting was breeding on burnt taiga forest areas further northeast, but there may be other explanations involving breeding time and migration strategy.

The migration route passes over land, managed forests with clearings, arable or at least arid grassland which means that the possibility to stop for foraging is rather good. A small data set from Swedish bird observatories (Sudre, Falsterbo, Ottenby, Nidingen; pers. comm.) also shows that the fat accumulation is moderate (mean fat class 3.50, std. err. 1.0, out of the 7 classes $0-6 ; n=32$ ) when the birds are about to leave Sweden in the autumn. The possible diet of both seed and insects also facilitates the finding of food. The capacity to store a huge fat reserve (doubling the weight or more) is well-known from the management of captured Ortolan Buntings in France before killing and eating (Steen 2014), but as far as we know this will not correspond to any normal need in the actual part of its western breeding range. The only part of the route where it might be necessary to build higher fat deposits is when passing dry areas between the Senegal-Mali border and Morocco, a distance of some 1500 kilometres.

\section{Conclusions}

The results show that Swedish Ortolan Buntings normally winter in a limited mountainous area in Guinea and Mali. The migration between breeding and wintering territories follows more or less the great circle. Probably all birds pass through the county les Landes in France where illegal tapping is going on. The migration is fairly synchronized in time and the birds arrive in Sweden in the middle of May and depart in the latter part of August. The spring migration proceeds somewhat faster than the autumn one, and the degree of fat storing before migration is moderate.

\section{Acknowledgements}

SOF BirdLife Sweden is gratefully acknowledged for support during several years. We thank Alvins fond for financial support and all the field workers for their excellent work and especially Tomas Brodin, Per Hansson, Magnus Bladh and Magnus Persson for their assistance. 


\section{References}

Becker, R.A. \& Wilks, A.R. 2013. maps: Draw Geographical Maps, $R$ version by Ray Brownrigg. Enhancements by Thomas P Minka.

Claessens, O. 1994. The situation of the Ortolan Bunting in France: Preset status, trends and possible causes of decrease. Pp. 123-128 in Ortolan-Symposium Ergebnisse (Steiner, H.M., ed.). Univ. Bodenskultur, Wien.

Ekstrom, P. 2004 An advance in geolocation by light. Mem. Natl. Inst. Polar Res. Special Issue 58: 210-226.

Hill, R.D. \& Braun, M.J. 2001. Geolocation by Light Level The Next Step: Latitude. Pp. $315-330$ in Electronic Tagging and Tracking in Marine Fisheries (J. Sibert \& J. Nielsen, eds.) Boston: Kluwer.

Meeus, J. 1991 Astronomical Algorithms. Richmond, Willman-Bell, Inc., 429 pp.

Nilsson, C, Klaassen, R.H.G. \& Alerstam, T. 2013. Differences in Speed and Duration of Bird Migration between Spring and Autumn, The American Naturalist 181: 837845 .

Lemke, H.W., Tarka, M., Klaassen, R.H.G., Åkesson, M., Bensch, S., Hasselquist, D. \& Hansson, B. 2013. Annual cycle and migration strategies of a trans-Saharan migratory songbird: a geolocator study in the great reed warbler. Plos One 8, e79209.

Lisovski, S. \& Hahn, S. 2013. GeoLight - processing and analyzing light-based geolocation in R. Methods Ecol Evol. 3: 1055-1059.

MacDonald, L.H. 1986. Natural Resources Development in the Sahel: The Role of the United Nations System (UNU, 95 pages)

Mount, H. 2010. The songbirds slaughtered for a Frenchman's supper. Daily Mail 7 September.

Ottosson, U., Ottvall, R., Elmberg, J., Green, M., Gustafsson, R., Haas, R., Holmqvist, N., Lindström, Å., Nilsson, I., Svensson, M., Svensson, S. \& Tjernberg, M. 2012. Fåglarna i Sverige - antal och förekomst. SOF, Halmstad.

R Core Team. 2013. R: A language and environment for statistical computing. R Foundation for Statistical Computing, Vienna, Austria. URL http://www.R-project.org/.

Runesson, B. 1996. Ortolansparven - en nyckfull och lurig rackare. Fåglar i Kvismaren 11: 9-17.

Steen, J. 2014. The Kitchen Magpie: A delicious melange of culinary curiosities, fascinating facts, amazing anecdotes and expert tips for the food-lover. Icon books.

Sondell, J., Brookes, C. \& Persson, M. 2011. Ortolan Bunting Emberiza hortulana at Kvismaren, central Sweden - breeding studies and suggested management. Ornis Svecica 21: 167-174.

Sondell, J., Hansson, P., Jerling, N-O., Lindström, J. \& Selstam, G. 2014. Inventering av ortolansparv på hyggen $i$ Norrland. Projektrapport.

Sondell, J. \& Runesson, B. 2010. Ortolansparven i Kvismaren 2009. Fåglar i Kvismaren 25: 21-24.

Stolt, B.-O. 1977. On the migration of the Ortolan Bunting, Emberiza hortulana L. Zoon 5: 51-61.

Stolt, B.-O. 1997. The Ortolan Bunting Emberiza hortulana L. in Sweden - migration and abundance. Pp. 101-111 in II Ortolan-Symposium, Ergebnisse (B. von Bülow, ed.) Th. Mann, Gelsenkirchen-Buer.

Stutchbury, B.J.M., McKinnon, E.A., Frazer, K.C., MacPherson, M. \& Stanley, C.Q. 2009. Tracking long- distance songbird migration by using geolocators. Science 323.5916: 896-896.

Svensson, L. 1992. Identification Guide to European Passerines. Stockholm.

Thoma, M. \& Menz, M.H.M. 2014. The Ortolan Bunting Emberiza hortulana wintering in West Africa, and its status as a passage migrant in Mauritania. Malinbus $36: 13: 31$.

Tryjanowski, P. 2000. Changing in breeding populations of some farmland birds in W Poland in relation to changes in crop structure, weather conditions and number of predators. Folia Zoologica 49: 305-315.

US Department of State. 2004. http://reliefweb.int/report/ senegal/locusts-invade-west-africas-grain-belt.

Walther et al. 2010 (17 authors). Database of Western Palaearctic birds migrating in Africa to guide conservation decisions. 12th Pan-African Ornithological Conference ISBN: 978-0-7992-2361-3.

Vepsäläinen, V., Pakkala, T. \& Piha, M. 2005. Population crash of the ortolan bunting Emberiza hortulana in agricultural landscapes of southern Finland. Annales Zoologici Fennici 42: 91-107.

\section{Sammanfattning}

Ortolansparven har minskat i Västeuropa under minst ett halvt sekel. Från södra Sverige är arten helt försvunnen som häckfågel och populationen i Mälardalen innefattar idag bara drygt ett hundratal par. Kvismare fågelstation har med inventeringar följt artens minskning i snart 50 år. År 2009 startade Föreningen Kvismare Fågelstation ett särskilt ortolanprojekt. Detta projekt lades 2011 samman med ett av Sveriges Ornitologiska Förening startat projekt med likartat syfte.

Flera orsaker till artens minskning ansågs möjliga. Förändringar i häckningsmiljön, förluster på grund av fångst i Frankrike under sträcket och problem under sträcket och i övervintringsområdet, listades som tänkbara viktiga orsaker. Ett problem i sammanhanget var att övervintringsområdet inte var känt. Genom att sätta ljusloggar på sjungande hannar borde detta problem kunna lösas (Figur 1). Våren 2012 sattes 10 loggar på ortolanhannar i Norrland och 29 loggar året efter, de flesta i närheten av Umeå. Det området hyser Sveriges starkaste stam av ortolansparv. Den lilla populationen i mellersta Sverige ansågs för sårbar för några omfattande loggförsök. Sex loggar sattes dock på i Kvismaren och Kungsör år 2013.

Våren 2013 kunde 3 hannar återfångas och året därpå 4, alla med data som visade att fåglarnas sträck i stort sett följde storcirkeln mellan häcknings- och övervintringsområdet (Figur 2, Appendix) från och till sydvästra Mali och i Guinea, ett begränsat område i Västafrika (Figur 3) där de tillbringat drygt fem vintermånader (Tabell 1). Alla 
fåglar passerade troligen genom fångstområdet för ortolansparv i sydvästra Frankrike. På grund av osäkra positionsdata i samband med höstdagjämningen kan vi dock inte leda detta $\mathrm{i}$ bevis. Fåglarna har sannolikt också passerat utan att rasta. Detta betyder dock inte att fångstrisken är liten. En fångstplats med lockande fåglar i burar på marken utgör en mycket stark dragningskraft.

Övervintringsområdet ligger på bergsluttningar som är upprinningsområde för många floder, t. ex. Gambia, Senegal och Niger. I området finns gles savannskog, bäckraviner men även odling av olika sädesslag såsom hirs och durra (Figur 4). Hirs är en omtyckt föda som bl.a. används för att locka fåglarna till fångstredskapen i Frankrike och till att föda upp fångade fåglar. Den ljusintensitet som loggarna registrerat dagtid under vintern är relativt låg (10 000-30 000 lux) jämfört med på våren i häckningsområdet (65 000 lux) vilket antyder att fåglarna på vintern söker sin föda på marken under högre vegetation och därmed blir svåra att observera.

\section{Appendix}

Compilation of migration periods, length of different periods between stops, actual coordinates, coordinate standard errors, and $95 \%$ confidence interval of the coordinates (c.i) for seven Ortolan Bunting males.

Sammanställning av sträckperioder, periodlängder mellan stopp, aktuella koordinater, standardavvikelser och 95-procentiga konfidensintervall för koordinaterna (c.i.) för sju hannar av ortolansparv.

\begin{tabular}{|c|c|c|c|c|c|c|c|c|c|c|}
\hline \multicolumn{2}{|c|}{ Period } & \multirow{3}{*}{$\begin{array}{l}\text { length } \\
\text { days }\end{array}$} & \multicolumn{4}{|c|}{ Longitude } & \multirow{3}{*}{${ }^{\circ} \mathrm{N}$} & \multicolumn{3}{|c|}{ Latitude } \\
\hline \multirow{2}{*}{$\begin{array}{c}\text { start } \\
\text { Y-M-D-h }\end{array}$} & \multirow{2}{*}{$\begin{array}{c}\text { end } \\
\text { Y-M-D-h }\end{array}$} & & ${ }^{\circ} \mathrm{E}$ & $\mathrm{SE}$ & $95 \%$ & c.i. & & SE & $95^{\circ}$ & 00 \\
\hline & & & & & low & high & & & low & high \\
\hline \multicolumn{11}{|l|}{ Bird No. B730 } \\
\hline $2012-07-1900$ & $2012-08-3123$ & 44 & 20,0 & 0,22 & 19,75 & 20,52 & 63,3 & 0,07 & 62,27 & 64,27 \\
\hline 2012-08-31 18 & 2012-09-09 17 & 9 & 22,1 & 0,50 & 21,63 & 22,47 & 54,7 & 0,70 & 53,47 & 56,15 \\
\hline 2012-09-09 17 & $2012-09-1623$ & 7,3 & 17,7 & 0,69 & 17,34 & 18,01 & 49,3 & 4,07 & 46,08 & 51,26 \\
\hline 2012-09-18 17 & $2012-09-2218$ & 4 & 2,2 & 0,76 & 2,13 & 2,21 & 22,0 & 21,41 & $-40,84$ & 33,02 \\
\hline $2012-09-2218$ & $2012-09-2806$ & 5,5 & $-2,3$ & 0,36 & $-2,37$ & $-2,28$ & 16,1 & 11,79 & $-5,38$ & 16,52 \\
\hline $2012-09-2906$ & $2012-10-0806$ & 9 & $-8,3$ & 0,14 & $-8,50$ & $-8,18$ & 39,7 & 2,92 & 29,14 & 46,29 \\
\hline $2012-10-1606$ & $2012-10-1922$ & 3,7 & $-10,2$ & 0,43 & $-10,41$ & $-10,02$ & 26,1 & 1,82 & 20,74 & 32,06 \\
\hline $2012-10-1922$ & $2012-10-2201$ & 2,1 & $-8,7$ & 0,57 & $-8,88$ & $-8,54$ & 22,0 & 1,96 & 17,67 & 25,30 \\
\hline $2012-10-2218$ & $2013-03-2206$ & 150,5 & $-10,9$ & 0,04 & $-11,12$ & $-10,71$ & 13,3 & 0,31 & 12,26 & 14,79 \\
\hline 2013-03-24 18 & 2013-03-29 18 & 5 & $-5,6$ & 0,36 & $-5,74$ & $-5,52$ & 17,1 & 12,87 & $-59,37$ & 26,74 \\
\hline $2013-03-2918$ & 2013-04-17 05 & 18,4 & $-7,7$ & 0,23 & $-7,89$ & $-7,60$ & 30,6 & 0,75 & 29,29 & 32,43 \\
\hline 2013-04-18 18 & 2013-04-21 18 & 3 & 6,3 & 0,97 & 6,16 & 6,40 & 42,0 & 1,36 & 40,67 & 44,30 \\
\hline 18 & $-04-2$ & 3 & 9,0 & 0,84 & 8,87 & 9,21 & 45,2 & 1,03 & 43,02 & 48,01 \\
\hline 2013-04-24 19 & $2013-04-2819$ & 4 & 16,0 & 0,55 & 15,74 & 16,34 & 51,1 & 0,45 & 49,35 & 53,36 \\
\hline 2013-04-29 18 & 2013-05-02 01 & 2,3 & 25,5 & 0,86 & 24,99 & 25,95 & 62,0 & 0,17 & 0,39 & 64,12 \\
\hline 2013-05-02 15 & $2013-05-1612$ & 13,9 & 23,4 & 0,96 & 22,95 & 23,84 & 59,2 & 0,28 & 58,17 & 60,63 \\
\hline 2013-05-16 12 & $2013-05-2121$ & 5,4 & 20,0 & 0,98 & 19,65 & 20,41 & 64,0 & 2,05 & 62,94 & 67,18 \\
\hline \multicolumn{11}{|l|}{ Bird No. B734 } \\
\hline $2012-07-2300$ & $2012-08-2602$ & 34 & 20,4 & 0,18 & 20,02 & 20,79 & 64,0 & 0,19 & 62,54 & 64,79 \\
\hline $2012-08-2818$ & $2012-09-0323$ & 6 & 15,0 & 0,30 & 14,72 & 15,29 & 53,7 & 0,94 & 52,19 & 55,31 \\
\hline 2012-09-04 18 & 2012-09-0900 & 4 & 0,5 & 0,34 & 0,51 & 0,53 & 44,4 & 1,20 & 42,13 & 47,17 \\
\hline 2012-09-0900 & $2012-09-1118$ & 3 & $-2,0$ & 0,60 & $-2,07$ & $-1,99$ & 40,5 & 0,68 & 37,08 & 44,32 \\
\hline $2012-09-1118$ & $2012-10-0106$ & 20 & $-7,7$ & 0,22 & $-7,81$ & $-7,52$ & 28,9 & 5,91 & 23,47 & 35,21 \\
\hline 2012-10-0106 & $2012-10-0806$ & 7 & $-8,9$ & 0,12 & $-9,10$ & $-8,76$ & 29,5 & 3,86 & 21,20 & 39,21 \\
\hline 2012-10-09 18 & $2012-10-1206$ & 3 & $-12,7$ & 0,17 & $-12,97$ & $-12,48$ & 20,4 & 2,30 & 12,35 & 27,84 \\
\hline $2012-10-1302$ & $2012-10-1618$ & 4 & $-12,1$ & 0,22 & $-12,31$ & $-11,85$ & 12,6 & 1,67 & 7,24 & 16,76 \\
\hline $2012-10-1618$ & 2013-04-04 06 & 170 & $-11,2$ & 0,03 & $-11,41$ & $-10,98$ & 13,2 & 0,31 & 12,25 & 14,52 \\
\hline 2013-04-07 19 & $2013-04-2112$ & 14 & $-7,3$ & 0,20 & $-7,43$ & $-7,15$ & 31,0 & 0,26 & 29,41 & 32,85 \\
\hline 2013-04-21 12 & 2013-05-02 05 & 11 & $-4,8$ & 0,25 & $-4,89$ & $-4,71$ & 38,0 & 0,96 & 36,67 & 39,61 \\
\hline 2013-05-02 05 & $2013-05-0423$ & 3 & $-0,1$ & 0,13 & $-0,06$ & $-0,06$ & 43,5 & 0,40 & 41,62 & 45,40 \\
\hline 2013-05-06 03 & 2013-05-08 03 & 2 & 4,5 & 0,49 & 4,37 & 4,54 & 48,1 & 0,11 & 46,59 & 50,20 \\
\hline
\end{tabular}




\begin{tabular}{|c|c|c|c|c|c|c|c|c|c|c|}
\hline $2013-05-0803$ & $2013-05-1123$ & 4 & 9,4 & 0,55 & 9,21 & 9,57 & 52,4 & 0,66 & 51,27 & 53,94 \\
\hline $2013-05-1123$ & $2013-05-1415$ & 3 & 15,3 & 1,47 & 15,02 & 15,60 & 59,1 & 0,46 & 57,74 & 60,51 \\
\hline $2013-05-1500$ & 2013-05-1800 & 3 & 19,4 & 1,06 & 19,00 & 19,73 & 64,0 & 1,19 & 63,30 & 68,32 \\
\hline \multicolumn{11}{|l|}{ Bird No. B736 } \\
\hline $2012-07-2300$ & 2012-08-19 13 & 28 & 19,9 & 0,28 & 19,49 & 20,25 & 63,0 & 0,06 & 62,05 & 64,05 \\
\hline 2012-08-20 01 & 2012-08-22 02 & 2 & 17,5 & 0,24 & 17,15 & 17,81 & 63,2 & 0,11 & 61,88 & 64,93 \\
\hline $2012-08-2219$ & $2012-08-2803$ & 5 & 13,9 & 0,40 & 13,65 & 14,18 & 57,5 & 0,75 & 56,10 & 58,96 \\
\hline $2012-08-2803$ & 2012-09-03 18 & 7 & 14,6 & 0,69 & NA & NA & 52,4 & 0,83 & NA & NA \\
\hline 2012-09-04 04 & 2012-09-05 21 & 2 & 9,2 & 0,68 & 8,98 & 9,33 & 49,5 & 0,69 & 46,99 & 52,48 \\
\hline 2012-09-05 21 & 2012-09-08 01 & 2 & 3,5 & 0,24 & 3,40 & 3,53 & 47,5 & 0,39 & 44,81 & 50,82 \\
\hline 09-08 01 & $-09-1318$ & 6 & 1,6 & 0,26 & 1,60 & 1,66 & 43,2 & 5,84 & 40,64 & 45,80 \\
\hline 05 & & 3 & $-3,8$ & 0,19 & $-3,88$ & $-3,74$ & 41,6 & 1,10 & $-70,03$ & 46,35 \\
\hline 618 & 18 & 14 & $-5,6$ & 13 & $-5,75$ & $-5,53$ & 38,7 & 38 & 26,05 & 39,92 \\
\hline 18 & 06 & 13 & $-8,0$ & 15 & $-8,18$ & $-7,88$ & 15,7 & 92 & 74 & 20,64 \\
\hline 11 & 201 & 3 & $-10,8$ & 0,48 & $-10,97$ & $-10,56$ & 12,0 & 3,29 & & 16,47 \\
\hline 613 & 201 & 171 & $-10,4$ & 0,04 & $-10,57$ & $-10,17$ & 14,0 & 0,18 & 73 & 14,99 \\
\hline 19 & 201 & 18 & $-6,2$ & 0,18 & $-6,36$ & $-6,12$ & 32,0 & 0,24 & 23 & 33,30 \\
\hline 619 & 201 & 5 & $-3,3$ & 0,33 & $-3,34$ & $-3,21$ & 37,3 & 0,91 & 82 & 39,39 \\
\hline-0119 & 519 & 4 & 0 , & 0,60 & 0,64 & 0,66 & 42,0 & 0,88 & 40,56 & 43,87 \\
\hline 5-05 19 & $5-0903$ & 3 & 5, & 0,54 & 5,55 & 5,77 & 47,3 & 0,72 & 45,96 & 49,18 \\
\hline $5-1000$ & $5-1122$ & 2 & 11,2 & 0,79 & 11,02 & 11,44 & 54,0 & 0,46 & 52,51 & 55,74 \\
\hline & 305 & 1 & 16,9 & 3,13 & 16,57 & 17,21 & 60,5 & 1,05 & 58,96 & 62,13 \\
\hline $2013-05-1323$ & & 7 & 9,2 & 0,72 & 18,88 & & 64,0 & 0,87 & & 64,93 \\
\hline \multicolumn{11}{|l|}{ Bird No. F170 } \\
\hline & 18 & 31 & 21,5 & 0,22 & 21,06 & 21,87 & 65,4 & 0,27 & 64,37 & 66,43 \\
\hline 2013-08-24 18 & 302 & 3 & 17,0 & 0,23 & 16,69 & 17,34 & 61,8 & 53,13 & 60,39 & 63,26 \\
\hline 810 & $9-0310$ & 6 & 14,6 & 0,30 & 14,34 & 14,89 & 58,6 & 0,44 & 57,19 & 59,88 \\
\hline 310 & 818 & 5 & 13,2 & 0,22 & 12,99 & 13,50 & 56,3 & 0,92 & 54,64 & 57,83 \\
\hline 17 & 318 & 3 & 8,0 & 0,47 & 7,82 & 8,12 & 45,5 & 2,09 & 41,84 & 48,62 \\
\hline 18 & 704 & 4 & 5,8 & 0,37 & 5,73 & 5,95 & 44,8 & 18,69 & 40,00 & 49,57 \\
\hline & & 2 & 4,6 & 0,13 & 4,53 & 4,71 & 39,8 & 2,08 & $-71,58$ & 45,62 \\
\hline 18 & 18 & 2 & $-3,1$ & 0,37 & $-3,19$ & $-3,07$ & $-48,2$ & 8,77 & $-59,83$ & 61,23 \\
\hline 17 & 21 & 11 & $-6,9$ & 0,25 & $-6,99$ & $-6,73$ & 32,7 &, 75 & ,79 & 42,46 \\
\hline 21 & 08 & 3 & $-8,6$ & 0,66 & $-8,76$ & $-8,43$ & 19,9 & 4,24 & 11,35 & 31,67 \\
\hline 06 & 02 & 6 & $-12,6$ & 0,53 & $-12,80$ & $-12,32$ & 9,3 & 1,63 & 5,89 & 13,61 \\
\hline 302 & 418 & 2 & $-9,4$ & 0,17 & $-9,63$ & $-9,27$ & 22,0 & 1,35 & 16,84 & 27,80 \\
\hline 418 & 206 & 19 & $-11,1$ & 0,12 & $-11,35$ & $-10,93$ & 13,0 & 0,38 & 11,54 & 14,64 \\
\hline 222 & 2014-0 & 164 & $-11,5$ & 0,04 & $-11,73$ & $-11,29$ & 13,0 & 0,15 & 12,04 & 14,05 \\
\hline 805 & 2014-05-04 05 & 16 & $-7,8$ & 0,25 & $-7,91$ & $-7,61$ & 33,1 & 1,21 & 31,75 & 34,41 \\
\hline 419 & $2014-05-0522$ & 1 & $-5,8$ & 0,37 & $-5,91$ & $-5,69$ & 39,1 & 0,67 & 36,80 & 41,22 \\
\hline 700 & 2014-05-07 19 & 20 & $-2,3$ & 0,00 & $-2,35$ & $-2,26$ & 42,1 & 3,10 & 40,16 & 44,42 \\
\hline 720 & 919 & 2 & 5 , & 0,11 & 5,23 & 5,44 & 46,1 & 0,07 & 44,15 & 48,14 \\
\hline 2014-05-09 21 & $2014-05-1223$ & 3 & 8,6 & 0,30 & 8,42 & 8,75 & 50,1 & 28,62 & 48,79 & 51,69 \\
\hline $2014-05-1303$ & $2014-05-1501$ & 2 & 11,9 & 0,11 & 11,63 & 12,08 & 56,3 & 0,14 & 54,83 & 57,95 \\
\hline $2014-05-1502$ & $2014-05-1723$ & 3 & 17,3 & 0,50 & 17,00 & 17,66 & 61,3 & 0,27 & 60,14 & 62,69 \\
\hline 2014-05-17 01 & 2014-05-18 21 & 2 & 19,8 & 2,22 & 19,46 & 20,21 & 63,0 & 3,88 & 61,26 & 64,08 \\
\hline 2014-05-18 21 & 2014-05-2708 & 9 & 21,7 & 1,41 & 21,32 & 22,14 & 65,0 & 41,12 & 63,97 & 66,24 \\
\hline
\end{tabular}

\section{Bird No. F178}

2013-07-09 01

2013-08-19 19

2013-08-23 08

2013-08-3018

2013-09-09 05

2013-09-13 18

2013-10-05 06
2013-08-18 02

2013-08-23 08

2013-08-28 03

2013-09-08 18

2013-09-12 18

2013-09-28 05

2013-10-11 22

$\begin{array}{lll}40 & 16,2 & 0,15 \\ 4 & 14,4 & 0,50 \\ 5 & 14,2 & 0,41 \\ 9 & 4,5 & 0,42 \\ 4 & 0,5 & 0,31 \\ 15 & -4,0 & 0,17 \\ 7 & -9,6 & 0,14\end{array}$

$\begin{array}{lll}0,05 & 58,01 & 59,96 \\ 22,92 & 52,49 & 55,95 \\ 0,42 & 49,53 & 52,90 \\ 0,48 & 42,69 & 46,20 \\ 0,92 & 38,12 & 44,38 \\ 9,07 & 16,87 & 41,47 \\ 2,90 & 22,30 & 38,90\end{array}$




\begin{tabular}{|c|c|c|c|c|c|c|c|c|c|c|}
\hline \multicolumn{2}{|c|}{ Period } & \multirow{3}{*}{$\begin{array}{c}\text { length } \\
\text { days }\end{array}$} & \multicolumn{5}{|c|}{ Longitude } & \multicolumn{3}{|c|}{ Latitude } \\
\hline \multirow{2}{*}{$\begin{array}{c}\text { start } \\
\text { Y-M-D-h }\end{array}$} & \multirow{2}{*}{$\begin{array}{c}\text { end } \\
\text { Y-M-D-h }\end{array}$} & & \multirow[t]{2}{*}{${ }^{\circ} \mathrm{E}$} & \multirow[t]{2}{*}{$\mathrm{SE}$} & \multicolumn{2}{|c|}{$95 \%$ c.i. } & \multirow[t]{2}{*}{${ }^{\circ} \mathrm{N}$} & \multirow[t]{2}{*}{ SE } & \multicolumn{2}{|c|}{$95 \%$ c.i. } \\
\hline & & & & & low & high & & & low & high \\
\hline 2013-10-12 18 & $2013-10-2018$ & 8 & $-12,1$ & 0,27 & $-12,37$ & $-11,91$ & 19,0 & 2,39 & 16,71 & 22,33 \\
\hline $2013-10-2106$ & 2013-11-21 06 & 31 & $-10,7$ & 0,04 & $-10,94$ & $-10,54$ & 15,1 & 0,64 & 14,03 & 16,48 \\
\hline $2013-11-2120$ & 2014-04-09 06 & 138 & $-12,0$ & 0,03 & $-12,21$ & $-11,75$ & 11,4 & 0,33 & 10,48 & 12,75 \\
\hline 2014-04-1305 & 2014-04-18 19 & 6 & $-9,0$ & 0,25 & $-9,17$ & $-8,83$ & 31,5 & 1,15 & 29,03 & 33,16 \\
\hline 2014-04-2000 & $2014-04-2523$ & 6 & $-6,1$ & 0,25 & $-6,25$ & $-6,02$ & 33,0 & 0,61 & 31,40 & 34,73 \\
\hline 2014-04-27 04 & 2014-04-29 19 & 3 & $-2,9$ & 0,15 & $-2,92$ & $-2,81$ & 39,6 & 0,35 & 37,59 & 41,43 \\
\hline 2014-04-29 19 & 2014-05-04 23 & 5 & 3,9 & 0,49 & 3,82 & 3,97 & 43,0 & 1,01 & 41,11 & 44,04 \\
\hline 2014-05-05 19 & $2014-05-1215$ & 7 & 12,2 & 0,67 & 11,96 & 12,43 & 52,0 & 0,37 & 50,58 & 52,99 \\
\hline 2014-05-12 19 & 2014-05-14 07 & 2 & 13,4 & 0,80 & 13,16 & 13,67 & 56,0 & 0,44 & 54,32 & 57,08 \\
\hline 2014-05-1407 & $2014-05-1623$ & 3 & 14,6 & 0,42 & 14,29 & 14,84 & 59,0 & 0,18 & 57,54 & 60,13 \\
\hline \multicolumn{11}{|l|}{ Bird No. F184 } \\
\hline $2013-07-1622$ & 2013-08-10 23 & 25 & 20,1 & 0,27 & 19,69 & 20,46 & 63,4 & 0,19 & 62,25 & 64,36 \\
\hline $2013-08-1012$ & $2013-08-1420$ & 4 & 16,0 & 0,68 & 15,66 & 16,27 & 61,4 & 0,40 & 60,24 & 63,00 \\
\hline 2013-08-15 19 & 2013-08-1906 & 3 & 13,0 & 0,27 & 12,72 & 13,21 & 58,0 & 0,56 & 56,40 & 59,47 \\
\hline 2013-08-1906 & 2013-08-2304 & 4 & 10,3 & 0,63 & 10,08 & 10,47 & 53,7 & 1,21 & 52,00 & 55,66 \\
\hline 2013-08-2304 & $2013-08-2601$ & 3 & 4,7 & 0,70 & 4,59 & 4,77 & 48,4 & 1,29 & 46,39 & 50,67 \\
\hline $2013-08-2601$ & 2013-08-28 19 & 3 & 0,1 & 0,53 & 0,09 & 0,10 & 43,8 & 1,42 & 41,47 & 46,48 \\
\hline 2013-08-28 19 & 2013-09-08 05 & 10 & $-2,8$ & 0,18 & $-2,89$ & $-2,78$ & 43,7 & 0,45 & 42,34 & 45,67 \\
\hline 2013-09-08 05 & $2013-09-2622$ & 19 & $-7,4$ & 0,08 & $-7,52$ & $-7,24$ & 43,3 & 6,03 & 42,07 & 48,01 \\
\hline $2013-09-2623$ & $2013-10-0218$ & 6 & $-7,2$ & 0,34 & $-7,32$ & $-7,05$ & 32,5 & 4,36 & 25,75 & 37,15 \\
\hline 2013-10-08 18 & $2013-11-1206$ & 35 & $-8,5$ & 0,07 & $-8,64$ & $-8,31$ & 8,1 & 0,75 & 6,40 & 9,55 \\
\hline $2013-11-1206$ & $2013-11-2912$ & 17 & $-11,6$ & 0,14 & $-11,81$ & $-11,37$ & 9,0 & 0,62 & 7,39 & 10,19 \\
\hline $2013-11-2912$ & 2014-04-08 19 & 130 & $-11,7$ & 0,07 & $-11,82$ & $-11,56$ & 12,3 & 0,47 & 11,46 & 13,19 \\
\hline 2014-04-11 19 & 2014-04-27 23 & 16 & $-9,3$ & 0,22 & $-9,46$ & $-9,11$ & 31,0 & 0,51 & 29,89 & 33,13 \\
\hline 2014-04-28 00 & 2014-04-29 22 & 2 & $-5,4$ & 0,20 & $-5,55$ & $-5,34$ & 35,0 & 0,45 & 32,33 & 37,75 \\
\hline 2014-04-29 22 & 2014-05-03 02 & 3 & $-3,3$ & 0,34 & $-3,40$ & $-3,28$ & 38,0 & 0,71 & 35,82 & 40,17 \\
\hline 2014-05-03 02 & 2014-05-07 03 & 4 & 0,9 & 0,47 & 0,84 & 0,88 & 44,0 & 2,62 & 41,96 & 45,49 \\
\hline 2014-05-06 19 & 2014-05-14 19 & 8 & 8,2 & 0,56 & 8,06 & 8,37 & 52,1 & 0,79 & 51,08 & 53,62 \\
\hline 2014-05-1501 & $2014-05-1623$ & 2 & 17,4 & 4,42 & 17,09 & 17,76 & 59,0 & 2,21 & 57,28 & 60,39 \\
\hline 2014-05-17 00 & 2014-06-01 11 & 16 & 22,9 & 1,24 & 22,44 & 23,30 & 63,0 & 0,93 & 61,13 & 63,83 \\
\hline \multicolumn{11}{|l|}{ Bird No. F191 } \\
\hline $2013-07-2200$ & 2013-08-25 19 & 35 & 19,9 & 0,23 & 19,54 & 20,30 & 63,4 & 0,21 & 62,35 & 64,44 \\
\hline 2013-08-26 02 & $2013-08-2803$ & 2 & 15,4 & 0,01 & 15,07 & 15,66 & 60,3 & 67,50 & $-100,5$ & 362,47 \\
\hline $2013-08-2803$ & 2013-09-03 03 & 6 & 13,1 & 0,72 & 12,85 & 13,35 & 55,8 & 0,47 & 54,33 & 57,38 \\
\hline 2013-09-05 04 & 2013-09-13 18 & 9 & 8,0 & 0,37 & 7,85 & 8,16 & 43,0 & 1,17 & 40,75 & 45,41 \\
\hline 2013-09-13 18 & $2013-09-1623$ & 3 & 1,6 & 0,27 & 1,58 & 1,64 & 44,0 & 1,38 & 38,73 & 48,73 \\
\hline 2013-09-17 05 & 2013-09-1909 & 2 & $-6,2$ & 0,05 & $-6,36$ & $-6,13$ & 32,3 & 44,34 & $-66,67$ & 41,32 \\
\hline 2013-09-19 09 & 2013-10-06 10 & 17 & $-5,5$ & 0,15 & $-5,52$ & $-5,31$ & 33,5 & 5,61 & 21,04 & 38,48 \\
\hline $2013-10-0610$ & 2013-11-05 18 & 30 & $-9,9$ & 0,13 & $-10,06$ & $-9,68$ & 16,2 & 0,76 & 14,58 & 18,11 \\
\hline 2013-11-05 18 & 2013-12-06 18 & 31 & $-9,7$ & 0,09 & $-9,87$ & $-9,50$ & 9,0 & 0,21 & 7,53 & 9,94 \\
\hline 2013-12-06 18 & 2014-03-09 23 & 93 & $-11,8$ & 0,06 & $-12,01$ & $-11,56$ & 12,0 & 0,27 & 10,84 & 12,97 \\
\hline
\end{tabular}

